DOI: http://dx.doi.org/10.4314/star.v4i2.30 ISSN: 2226-7522(Print) and 2305-3372 (Online) Science, Technology and Arts Research Journal Sci. Technol. Arts Res. J., April-June 2015, 4(2): 228-231 Journal Homepage: http://www.starjournal.org/

Original Research

\title{
Survey on Perception of Equine Euthanasia among Rural Communities of Ethiopia
}

\author{
Ayele Gizachew $^{1^{\star}}$, Hawi Jaleta ${ }^{1}$, Tadesse Birhanu ${ }^{1}$ and Josep Subirana ${ }^{2}$ \\ ${ }^{1}$ School of Veterinary Medicine, Wollega University, Post Box No: 395, Nekemte, Ethiopia \\ ${ }^{2}$ World Horse Welfare, Anne Colvin House, Snetterton, Norwich NR16 2LR, United Kingdom
}

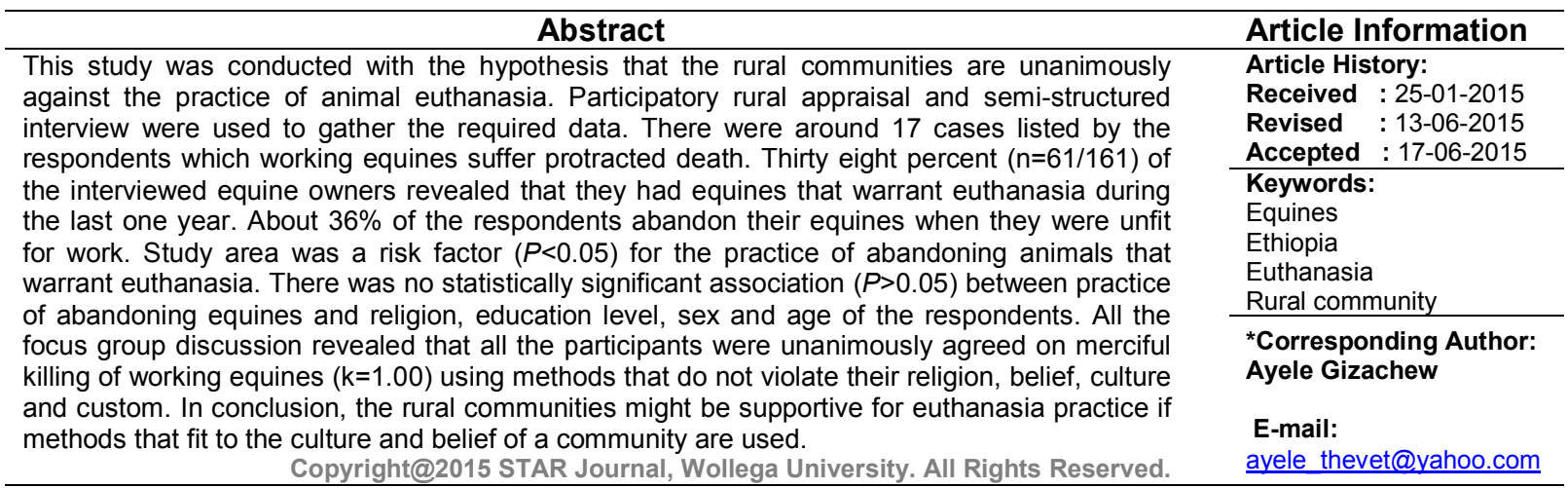

\section{INTRODUCTION}

The term euthanasia is derived from the Greek terms eu meaning good and thanatos meaning death (Webster's dictionary, 1999). Euthanasia is the act of inducing humane death in an animal. It is done with the highest degree of respect and with an emphasis on making the death as painless and distress free as possible. Euthanasia techniques should result in rapid loss of consciousness followed by cardiac or respiratory arrest and the ultimate loss of brain function. In addition, the technique should minimize distress and anxiety experienced by the animal prior to loss of consciousness (AVMA, 2007).

Although equines are the lifeline of most farmers in Ethiopia they have been subjected to various problems, i.e., they have been ill-treated, overloaded, beaten and abandoned. The reasons for these inhumane treatments of equines are multifactorial. Lack of awareness, cruelty and poverty are some of the potential reasons for the prevailing bad welfare practice on working equines in Ethiopia (Svendson, 1998).

One of the major welfare problems of working equines in Ethiopia is suffering from untreatable diseases or injuries with reasonable effort, such as, terminal illness, rabies, permanent bone breakage of limbs and other serious or chronic illness (e.g. Epizootic lymphangitis). Most of these equines stay with pain and suffering until they die of the problem (Ayele, 2006). In most part of Ethiopia, euthanasia of animals in general and working equines in particular has not been undertaken for various reasons. One key reason is that the culture and custom of rural communities in the country concerning euthanasia is not well understood and documented. This study was therefore designed with the specific objectives of documenting the communities' perception and recommendation on humane killing, current practices on equines unfit for work and the common equine diseases which make them unfit for work.

\section{MATERIALS AND METHODS}

\section{Study Area Description}

Lemmo District

The administrative town of Lemmo, Hossana, is located $231 \mathrm{Kms}$ south of the capital, Addis Ababa. The human population living in the Lemmo woreda was estimated at 150,719 . About $85 \%$ of the population in Lemmo woreda was living in rural areas. The wereda had 15,926 donkeys, 5,820 mules and 7,839 horses.

\section{Shashego District}

The administrative town of the woreda, Bonosha is found at about72 kms southeast of Hossana. The human population living in the Shashego woreda is estimated at 127,172. About $94 \%$ of the population in Shashego woreda is living in rural areas. Shashego had 10,516 donkeys, 1,147 mules and 1,810 horses. 


\section{Meskan District}

The administrative town of Meskan, Butajira, is located $133 \mathrm{kms}$ south of the capital, Addis Ababa. In 2009 the human population living in the Meskan woreda was estimated at 172,682 . About $91.7 \%$ of the population in Meskan woreda is living in rural areas. Meskan had 8,594 donkeys, 130 mules and 2,728 horses.

\section{Study Methodology}

Lemmo, Meskan and Shashogo Districts were randomly selected from South Nation and Nationalities People Region (SNNPR). From each district 7 villages were selected using systemic random sampling technique. Semi-structured interview and Participatory Rural Appraisal tools were used to gather the required data. A total of 161 voluntary people were individually interviewed and 21 focus group discussions (FGDs) were conducted, . There were 10-12 equine owners in each FGD irrespective of sex, gender and economical status. The FGDs were held in the national working language and then the summaries were translated in to English. Field veterinarians facilitated the discussion.

\section{Data Analysis}

All primary collected data were entered into excel spread sheet and analyzed for descriptive statistics using SPSS 20.0 for windows. Kappa statistics was used to see the degree of agreement among FGDs.

\section{RESULTS AND DISCUSSION}

Individual Interview Findings

Out of the total 161 equine owners interviewed, 143 $(88.8 \%)$ were male and the rest $18(11.2 \%)$ were females. One hundred and fifty one $(93.8 \%)$ of the interviewees were head of the households where as the rest $10(6.2 \%)$ were family members. The education level of the respondents varied from illiterate to high school graduates (Table 1). Almost all (99\%) of the respondents were selfemployed. The minimum and maximum age of the respondents was 20 and 80 years, respectively.

Table 1: Education level of the respondents in the study districts, Ethiopia

\begin{tabular}{lccc}
\hline Education level & Frequency & $\begin{array}{c}\text { Percent } \\
(\mathbf{\%})\end{array}$ & $\begin{array}{c}\text { Cumulative } \\
\text { Percent }\end{array}$ \\
\hline No formal & 60 & 37.3 & 37.3 \\
education & & & \\
Elementary & 64 & 39.8 & 77.0 \\
High school & 37 & 23.0 & 100 \\
\hline Total & $\mathbf{1 6 1}$ & $\mathbf{1 0 0}$ & - \\
\hline
\end{tabular}

There were around 17 cases listed by the respondents which working equines suffer protracted death, some being abandonment and eaten by wild animals (Table 2). A fungal disease called Epizootic lymphangitis was the most frequently listed diseases that exposed working equines to protracted death, abandonment and being eaten by wild animals.

Thirty eight percent $(n=61 / 161)$ of the total interviewed equine owners revealed that they had equines that warrant euthanasia during the last one year. This was not statistically different $\left(X^{2}=2.105, P=0.349\right)$ among the study districts. Sixty four percent of these owners kept their unwanted equine at home till death where as the rest owners abandoned their unwanted equines.
Table 2: Summarized problems from which working equines suffered protracted death and abandonment the study districts

\begin{tabular}{|c|c|c|c|}
\hline №. & $\begin{array}{c}\text { Type of } \\
\text { cases/problems }\end{array}$ & $\begin{array}{l}\text { No of } \\
\text { respondents } \\
\text { listed the } \\
\text { problem }\end{array}$ & $\begin{array}{c}\text { Percent } \\
(n=61)\end{array}$ \\
\hline 1 & Epizootic lymphangitis & 9 & $14.8 \%$ \\
\hline 2 & Hind quarter paralysis & 8 & $13 \%$ \\
\hline 3 & Impactive colic & 4 & $6.6 \%$ \\
\hline 4 & Fibroblastic sarcoids & 4 & $6.6 \%$ \\
\hline 5 & Limb bone fracture & 5 & $8.2 \%$ \\
\hline 6 & Limb joint dislocations & 3 & $4.9 \%$ \\
\hline 7 & Proud flesh & 4 & $6.6 \%$ \\
\hline 8 & Severe hyena bite & 1 & $1.6 \%$ \\
\hline 9 & Blindness & 2 & $3.3 \%$ \\
\hline 10 & African Horse Sickness & 4 & $6.6 \%$ \\
\hline 12 & Ulcerative lymphangitis & 5 & $8.2 \%$ \\
\hline 13 & Deformed hoof & 1 & $1.6 \%$ \\
\hline 14 & Suspected mange case & 3 & $4.9 \%$ \\
\hline 15 & Severe bee sting & 1 & $1.6 \%$ \\
\hline 16 & Rabies & 2 & $3.3 \%$ \\
\hline 17 & Very old age & 5 & $8.2 \%$ \\
\hline \multicolumn{2}{|r|}{ Total } & 61 & $100 \%$ \\
\hline
\end{tabular}

Binary logistic regression analysis revealed that study area was a risk factor $(P<0.05)$ for the practice of abandoning animals that need euthanasia. Most of the abandoning was exercised in Lemmo district. The respondents in Meskan said that it is culturally forbidden to abandon animals. Locally they call it "Kafir" to mean sinful. There was no statistically significant association $(P>0.05)$ between practice of abandoning equines and religion, education level, sex and age of the respondents

All the respondents dispose the dead equines by leaving them in the field, i.e., there was no environmentally friendly disposal of dead equines. This has association with their belief that, "if a hyena is not supplied with dead equines it will affect human beings". In addition, some of the respondents believe that hyena is the best cleaner of the environment; there is no leftover.

\section{Focus Group Discussion Findings}

The focus group discussion revealed the common irreversible diseases of equines, the rural communities' perception on euthanasia and practice of disposal of dead equines.

\section{Common Irreversible Diseases of Equines in the Study Districts}

In Meskan district, overall seven FGDs were held in seven different randomly selected villages. There were around 15 health problems listed by the participants that make working equines unfit for work in this district. The information from the focus group discussions revealed that owners in Meskan district kept terminally sick equines at home with some traditional treatments till death (Table 3 ). There was perfect agreement among the FGDs in the district on this humane practice $(\mathrm{k}=1.00)$. 
Table 3: Common problems of equines for protracted death and abandonment in Meskan district

\begin{tabular}{|c|c|c|c|c|}
\hline No & Local name & Scientific name & $\begin{array}{c}\text { Frequency of the } \\
\text { case (high, low, } \\
\text { medium) }\end{array}$ & $\begin{array}{c}\text { Measures taken by } \\
\text { the owners }\end{array}$ \\
\hline 1. & Jibril & Hind quarter paralysis & Iow & * \\
\hline 2. & Werena & Abdominal distention & low & * \\
\hline 3. & Kuro (yesene beshita) & AHS & high & * \\
\hline 4. & Nidift & Epizootic lymphangitis & high & * \\
\hline 5. & Igre Iga & Bone spavin & high & * \\
\hline 6. & Yeayin Girdosh & Impaired vision & low & * \\
\hline 7. & Biliz & Proud flesh & midium & * \\
\hline 8. & Kafir & Suspected mange & high & * \\
\hline 9. & Gembet & Severe back sore & high & * \\
\hline 10. & Kire & Dislocation & high & * \\
\hline 11. & Sibrat & Bone fracture & low & * \\
\hline 12. & maz & Hoof related problem & low & * \\
\hline 13. & Menkes & colic & high & * \\
\hline 14. & Kintibiye & Sarcoid & medium & * \\
\hline 15. & Kerez & Old age & Medium & * \\
\hline
\end{tabular}

*Do every effort to treat the animal by using herbal medicine and keep at home till death

In Lemmo district, a total of seven FGDs were held in seven different randomly selected peasant associations (PAs). There were around 10 health problems listed by the participants that make working equines unfit for work. The information from focus group discussions revealed that owners in the interviewed area abandoned terminally sick equines (Table 4). There was no agreement in the practice of abandoning sick equines between Lemmo and Mesken district $(\mathrm{k}=0.00)$.

Table 4: Common problems of equines for protracted death and abandonment in Lemmo district

\begin{tabular}{lcccc}
\hline No & Local name & Scientific name & $\begin{array}{c}\text { Frequency of } \\
\text { the case (high, } \\
\text { low, medium) }\end{array}$ & $\begin{array}{c}\text { Measures taken } \\
\text { by the owners }\end{array}$ \\
\hline 1. & Tusha/Nidifa & E. lymphangitis & high & Abandon \\
2. & Chijebo & Hind quarter paralysis & high & Abandon \\
3. & chechebsa & U. lymphangitis & high & Abandon \\
4. & Edoticho & Sarcoids & high & Abandon \\
5. & Kafira & Dermatitis & high & Abandon \\
6. & Ekamako/Ekamima/Ekancha & Bone fracture & high & Abandon \\
7. & Mikicha & unknown & high & Abandon \\
8. & Elitisa & blindness & high & Abandon \\
9. & Wush Jebo/Mecharanch & Rabies & high & Abandon \\
10. & Tigena & Chronic hoof problem & high & Abandon \\
\hline
\end{tabular}

The FGDs in Shashogo district revealed that there were about seven common diseases or problems which make working equines unfit for work (Table 5). Severe epizootic lymphangitis, very old age and paralysis of hind quarter were the reasons the owners in the district abandon their equines. For the other health problems the communities keep equines at home till death. There was no agreement in the practice of abandoning equines unfit for work $(k=0.00)$ between Lemo and this district. However, there is moderate agreement $(\mathrm{k}=0.41)$ with Meskan districts.

Table 5: Common problems of equines for protracted death and abandonment in Shashogo district

\begin{tabular}{lcccc}
\hline No & Local name & Scientific name & $\begin{array}{c}\text { Frequency (high, } \\
\text { low, medium) }\end{array}$ & $\begin{array}{c}\text { Measures taken by } \\
\text { the owners }\end{array}$ \\
\hline 1. & Hekem Loko & Permanent bone breakage & low & Keep at home \\
2. & Elkoka/Eljebo & Blindness & low & Keep at home \\
3. & Nidift/Dubika & E pizootic lymphangitis & medium & abandon \\
4. & Chegena & Hind quarter paralysis & low & abandon \\
5. & Chebchebssa & Ulcerative lymphangitis & low & Keep at home till death \\
6. & Lominima/Lomonako & Old age & high & abandon \\
7. & Kafir & Unidentified skin problem & medium & Keep at home till death \\
\hline
\end{tabular}


Community Perception and Practice on Euthanasia in the Study Districts

In Mesken district, although they agreed that an animal should put to a sleep from its suffering, they have reservations on the use of gun for euthanasia. They recommended professional based euthanasia using injections if available. The groups in this district emphasized that abandonment of animals for any reason should be considered as a crime. "We have to try our best to relieve the animal from its pain and suffering using the best and available methods", they said.

In Lemmo districts where abandoning of working equines unfit for work was exercised highly, people basically agree with merciful killing. The community said "prevention from these irreversible diseases should be given priority. Once one of these diseases occurs, the animal should be taken to health posts or traditional healers. If the situation becomes irreversible, euthanasia and proper disposal (burial) should be the last step". The recommended killing methods by the community were: shooting with bullet, strangulating using ropes, blow to the back of the head and blow to the front head.

Similar to Meskan and Shashogo districts, the FGD participants in Lemmo district were principally agree with humane killing but they were against shooting with gun. The community said "it is very sinful to shoot by ourselves an animal that we brought-up and that has served us". All said that it is by far better to abandon an animal than shooting with gun which is "Kafir" (sinful). The community recommended other euthanasia methods like injections or giving some poisons with feed. There was a perfect agreement $(\mathrm{k}=1.00)$ among all the districts in the practice of putting an animal to sleep which shows the communities are supportive for euthanasia practice by government or any other non-governmental organizations.

\section{CONCLUSIONS}

From this study it could be concluded that many working equines in the study districts were suffering from incurable diseases that warrant humane killing. All of the contacted communities agree with merciful killing of animals but in the communities the materials, knowledge and expertise necessary to humanely kill unwanted equines was not available. The methods of euthanasing animals are highly influenced by the belief and culture of the communities. Thus, work on prevention of equine diseases that are not amenable to treatments, designing euthanasia methods that fits to the culture and belief of a community and understand the government legal issues that may surround euthanasia were recommended.

\section{Acknowledgements}

We would like to acknowledge the livestock development agencies of each district. The equine owners and all individuals who participated on the study also deserve acknowledgment.

\section{Conflict of Interest}

Authors declared no conflict of interest.

\section{REFERENCES}

Ayele, G., Gebreab, F., Bojia, E., Getachew, M., Fanta, A., Tesfaye, M., Amare, B., Dereje, N., Chala, C., Asefa, A., Anzuino, J. and Trawford, A. F. (2006). Principal health problems of donkeys in Dugda Bora District of Ethiopia Presented at $5^{\text {th }}$ international colloquium of working equines, (30 October-2 Novemeber 2006). Addis Ababa, Ethiopia.

American Veterinary Medical Association (AVMA) (2007). Guidelines on Euthanasia (Formerly Report of the AVMA Panel on Euthanasia) June, 2007.

Svendson, E. D. (1997). The Professional Hand Book of the Donkey, $3^{\text {rd }}$ edition, Whittet Books Limited, 18 Anley road London W14 OBY.

Webster's ninth new collegiate dictionary (1990) Springfield: Merriam-Webster Inc. 